Proceedings

\title{
Risks for Population Health from Atmospheric Air Pollution in the City of Kazan ${ }^{+}$
}

\author{
Natalya V. Stepanova * and Suryana F. Fomina \\ Kazan Federal University (KFU), Institute of Fundamental Medicine and Biology, Kremlevskaya st. 18, \\ Kazan 420008, Russia; medbiol@kpfu.ru \\ * Correspondence: stepmed@mail.ru; Tel.: +7-917-399-9907 \\ + Presented at the 1st International Electronic Conference on Environmental Health Sciences, \\ 15 November-7 December 2018; Available online: https://iecehs-1.sciforum.net/.
}

Published: 14 November 2018

\begin{abstract}
The assessment of non-carcinogenic risk for the population health from chemicals coming from exhaust gases of motor transport citywide and in certain districts of the city of Kazan was performed. The calculation was carried out according to the results of the laboratory and instrumental tests carried out by "Center of Hygiene and Epidemiology in the Republic of Tatarstan" for the period from 2010 to 2016. The general toxic effect on the organs of the respiratory system from $42.5 \%$ to $62.0 \%$ in the city and districts is the result of exposure to the total fraction of total dust (TSP), particulate matter (PM)10, and $\mathrm{PM}_{2.5}$. Population risk of the total TSP impact made 1244 cases of additional deaths per year among the city population, apart from external causes. In Vakhitovsky and Sovetsky districts, this index for the whole population made 86 and 281 per year, respectively. The absence of data on the age-specific death rate in the districts did not allow for calculating the given indices for certain age groups. Damage associated with total morbidity of asthma among the cumulative city population caused by the exposure to PM10 made 486 cases in adults and 67 cases in children per year. Damage from the exposure to $\mathrm{PM}_{2.5}$ made 332 additional deaths from all causes (14.6\%), 1727 from cardiovascular diseases $(4.5 \%)$, and 18 from respiratory diseases $(6.0 \%)$. Currently, the assessment of mortality and diseases caused by the air pollution is the starting point for development or correction of regulatory actions in the field of the environmental and the population health protection at regional level.
\end{abstract}

Keywords: atmospheric air; vehicles; monitoring; public health risk

\section{Introduction}

Numerous epidemiological studies carried out during the last decades indicate adverse health effects from exposure to atmospheric air pollution [1-4]. A new WHO air quality model confirms that 92\% of the world's population lives in places where air quality levels exceed WHO limits [1]. Suspended substances (solids-particulate matter (PM) 2.5 and $\mathrm{PM}_{10}$ ), deeply penetrating and depositing in different parts of the airways, having various sources and composition and causing cardiovascular diseases, including stroke, lung cancer, chronic obstructive pulmonary diseases, respiratory infections, and pneumonia in particular, have serious consequences for human health [5-8]. New studies include a large volume of evidence, which are at present under consideration of WHO in the REVIHAAP (Review of evidence on health aspects of the atmospheric air pollution) and HRAPIE (health risks from air pollution in Europe) projects, and confirm that the external air pollution is an important health risk factor [9-11]. Monitoring of concentrations and decrease of the air pollution with fine suspended particulates $\mathrm{PM}_{2.5}$ and $\mathrm{PM}_{10}$ in large industrial cities, to which the city of Kazan refers, is a vital task of social and hygienic monitoring and management of population health risks. 
The aim of this research was to assess the population health risk from chemicals coming with atmospheric air in the city and in two (Sovetsky and Vakhitovsky) districts of the city of Kazan on account of recommendations on the use of concentration-response functions concerning mortality and morbidity associated with long-term exposure of particulate matter (PM).

\section{Materials and Methods}

Pollution characteristics of the city of Kazan in Vakhitovsky and Sovetsky city districts are given according to the results of the laboratory and instrumental tests carried out by "Center of Hygiene and Epidemiology in the Republic of Tatarstan" at the monitoring points for the period from 2010 to 2016. Exposure was assessed on the basis of measured average annual concentrations on the territory all over the city and two districts. Annual data on the population size in the city of Kazan and mortality from various causes and age groups (coded in accordance with the 10th International Classification of Diseases (ICD)) were obtained from the Annual Statistical Bulletin "Natural population migration of the urban and municipal districts of the Republic of Tatarstan" for the period of 2010-2016. The target population included all permanent residents living in the city of Kazan and two districts distinguished by location of industrial enterprises and plants, as well as vehicle density. Vakhitovsky district - the central part of the city - with a total standard residential population of about 89.0 thousand people, and Sovetsky district located in the northeast and east parts with a population of more than 311.0 thousand people, were selected for study. The calculation of risk of developing non-carcinogenic effects from pollutants contained in the atmospheric air was carried out in accordance with Guidelines for assessing the population health risk on exposure to chemicals polluting the environment (Manual R 2.1.10.1920-04) [12]. To identify the number of attribute-based outcomes resulting from the analyzed impact of TSP, $\mathrm{PM}_{10}$, and $\mathrm{PM}_{2.5}$, the concentration-response function (CRF) expressed in terms of the value of relative risk (OR) per $10 \mu \mathrm{g} / \mathrm{m}^{3}$ and the frequency of analyzed health problems per 1000 of the population were used [9-11].

\section{Results and Discussion}

An analysis of the used laboratory and instrumental studies of atmospheric air in the city of Kazan showed that 7-13 pollutants are controlled in given points. Most of them (nitrogen dioxide, sulphur dioxide, carbon oxide, suspended particulates, and formaldehyde) are on the list of priority substances contained in the atmospheric air of the cities/towns of the Russian Federation and the inventory list of toxic substances' emission of the U.S. Environmental Protection Agency (U.S. EPA). For the period under study, the contribution of the automobile transport to atmospheric pollution in Kazan remained high and contributed $69.4 \%-73.8 \%$ of the total gross emissions. The atmospheric air pollution level for the period of 2010-2014 in the city of Kazan was characterized as "high": SI (standard index) 13.1-13.6; API (a complex air pollution index taking into account several impurities) 7-13. From the year of 2014, after introduction of amendment No. 11 into Hygienic Norms GN 2.1.6.1338-03 "Maximum allowable concentrations (MAC) of pollutants in atmospheric air of populated areas" and the introduction of new sanitary and hygienic standards for concentrations of formaldehyde and phenol, the pollution level in the city was determined as "low", being underestimated by a factor of more than 3 and 2 correspondingly in comparison with the former level. The threshold concentration values of total dust (TSP) $\left(0.01 \mathrm{mg} / \mathrm{m}^{3}\right), \mathrm{PM}_{10}\left(0.0075 \mathrm{mg} / \mathrm{m}^{3}\right)$, and PM2.5 $\left(0.0035 \mathrm{mg} / \mathrm{m}^{3}\right)$ were used as the background exposure levels (Table 1). 
Table 1. Results of assessing non-carcinogenic risk from chemicals polluting atmospheric air for the population health in certain districts of the city of Kazan.

\begin{tabular}{|c|c|c|c|c|c|c|c|c|c|c|}
\hline Substances & $\begin{array}{c}\mathrm{RfC} \\
\mathrm{mg} / \mathrm{m}^{3}\end{array}$ & $\begin{array}{c}\mathrm{M}^{\mathrm{a}}, \\
\mathrm{mg} / \mathrm{m}^{3}\end{array}$ & HQ & $\%$ & $\begin{array}{c}\mathrm{M}^{\mathrm{a}}, \\
\mathrm{mg} / \mathrm{m}^{3}\end{array}$ & HQ & $\%$ & $\begin{array}{c}\mathrm{M}^{\mathrm{a}}, \\
\mathrm{mg} / \mathrm{m}^{3}\end{array}$ & HQ & $\%$ \\
\hline Points & & \multicolumn{3}{|c|}{ Kazan } & \multicolumn{3}{|c|}{ Vakhitovsky district } & \multicolumn{3}{|c|}{ Sovetsky district } \\
\hline TSP & 0.075 & 0.148 & 1.98 & 17.09 & 0.15 & 2 & 14.18 & 0.153 & 2.04 & 17.29 \\
\hline Sulphur Dioxide & 0.05 & 0.001 & 0.02 & 0.17 & 0 & 0 & 0.00 & 0 & 0 & 0.00 \\
\hline Carbon Oxide & 3 & 1.771 & 0.59 & 5.11 & 3.097 & 1.032 & 7.32 & 3.874 & 0 & 10.94 \\
\hline Nitrogen Dioxide & 0.04 & 0.070 & 1.74 & 15.04 & 0.09 & 2.25 & 15.96 & 0.105 & 1.29 & 22.25 \\
\hline Nitrogen Oxide & 0.06 & 0.024 & 0.39 & 3.41 & 0 & 0 & 0 & & 2.63 & 0 \\
\hline Hydrogen Sulphide & 0.002 & 0.001 & 0.57 & 4.91 & 0 & 0 & 0 & 0 & 0 & 0 \\
\hline Phenol & 0.006 & 0.001 & 0.19 & 1.66 & 0 & 0 & 0 & 0 & 0 & 0 \\
\hline Ammonia & 0.1 & 0.022 & 0.22 & 1.93 & 0 & 0 & 0 & 0 & 0 & 0 \\
\hline Benz(a)pyrene & 1 & 1.982 & 1.98 & 17.14 & 0 & 0 & 0 & & 0 & 0 \\
\hline Formaldehyde & 0.003 & 0.008 & 2.63 & 22.75 & 0.002 & 0.667 & 4.73 & 0 & 0 & 0.00 \\
\hline $\mathrm{PM}_{10}$ & 0.05 & 0.081 & 1.63 & 12.99 & 0.098 & 1.96 & 13.90 & 0.041 & 0.82 & 6.95 \\
\hline $\mathrm{PM}_{2.5}$ & 0.015 & 0.038 & 2.57 & 20.47 & 0.052 & 3.467 & 24.59 & 0.025 & 1.67 & 14.12 \\
\hline Carbon (soot) & 0.05 & 0 & 0 & 0 & 0.136 & 2.72 & 19.29 & 0.168 & 3.36 & 28.47 \\
\hline $\mathrm{HI}^{\mathrm{b}}$ & & & 14.51 & & & 14.09 & & & 11.8 & \\
\hline
\end{tabular}

a Average concentrations; ${ }^{b} \mathrm{RfC}$-reference concentration; ${ }^{\mathrm{c}} \mathrm{HQ}$-hazard quotient; $\mathrm{d} \mathrm{HI}-$ the total hazard index with account of total dust (TSP), particulate matter (PM)10, and PM2.5 fractions.

An analysis of the hazard index (HI) in the city and the city districts showed that they are within the same limits and correspond to the extremely high risk level (HI more than 10) [13]. According to the assessment results, the total impact of suspended particulates of $\mathrm{PM}_{2.5}, \mathrm{PM}_{10}$, and total dust (TSP) contribute most to the total value of non-carcinogenic risk in the city of Kazan (42.5\%) and the districts under study (in Vakhitovsky district-52.7\%, in Sovetsky district-59.9\%). The primary contribution in the city of Kazan is determined by nitrogen dioxide and formaldehyde $(15 \%-22.7 \%)$, and in Vakhitovsky and Sovetsky districts, by nitrogen dioxide and carbon (soot), at $16.0 \%-22.25 \%$ and $19.3 \%$ and $28.5 \%$, respectively. Organs of the respiratory system $(\mathrm{HI}=11.93 ; 13.06$ and 10.51$)$ are highly vulnerable to the risk of developing general toxic effects on chronical exposure to chemicals coming from atmospheric air in the city and districts as a result of exposure to TSP total fracture (from $42.5 \%$ to $62.0 \%)$.

According to WHO and depending upon availability of data in calculations, we used the recommended values of relative risk (RR) for additional number of health outcomes and concentration-response functions (CRF) per $10 \mu \mathrm{g} / \mathrm{m}^{3}$ associated with exposure to $\mathrm{PM}_{10}$ and $\mathrm{PM}_{2.5}$. Population risk of the total suspended particulates' impact made 1244 cases of additional deaths per year among the city population, apart from external causes. The number of additional deaths for the whole population in different age groups of the population in the city of Kazan made from 7.8 to 1043 cases in retirement-age adults per year (Table 2). 
Table 2. Additional number of outcomes per year from the effect of suspended particulates in the city of Kazan. ICD-International Classification of Diseases; RR-relative risk.

\begin{tabular}{|c|c|c|c|c|c|}
\hline $\begin{array}{l}\text { Receptor Point } \\
\text { (of the District) }\end{array}$ & Health Impacts & ICD-10 & $\begin{array}{c}\text { Population } \\
\text { Groups }\end{array}$ & $\begin{array}{c}\text { RR per } \\
10 \mu g / \mathrm{m}^{3}\end{array}$ & $\begin{array}{c}\text { The Frequency of } \\
\text { Responses }\end{array}$ \\
\hline \multicolumn{6}{|c|}{ TSP } \\
\hline Kazan & All-cause mortality & & All & & 1244 \\
\hline \multicolumn{6}{|c|}{$\mathrm{PM}_{10}$} \\
\hline Kazan & Mortality from CVD ${ }^{a}$ & J00-99 & All & 1.014 & 574 \\
\hline Kazan & Mortality from RD ${ }^{b}$ & J00-99 & All & 1.034 & 53 \\
\hline Kazan & All-cause mortality & $\mathrm{A}_{00}-\mathrm{R}_{99}$ & All & 1.0074 & 565 \\
\hline \multirow[t]{2}{*}{ Kazan } & Prevalence of bronchitis & $\mathrm{J}_{40-43}$ & $0-14$ & 1.08 & 122 \\
\hline & Prevalence of bronchitis & $\mathrm{J}_{40-43}$ & $18+$ & 1.117 & 9919 \\
\hline Vakhitovsky district & \multirow{2}{*}{ Prevalence of bronchitis } & $\mathrm{J}_{40-43}$ & $0-14$ & 1.08 & 15 \\
\hline Sovetsky district & & $\mathrm{J}_{40-43}$ & $0-14$ & 1.08 & 9 \\
\hline Kazan & \multirow{4}{*}{$\begin{array}{l}\text { Health encounters for } \\
\text { asthma }\end{array}$} & $\mathrm{J}_{45-46}$ & $0-14$ & 1.0512 & 486 \\
\hline Kazan & & $\mathrm{J}_{45-46}$ & $18+$ & 1.004 & 67 \\
\hline Vakhitovsky district & & $\mathrm{J}_{45-46}$ & $0-14$ & 1.0512 & 3398 \\
\hline Sovetsky district & & J45-46 & $0-14$ & 1.0512 & 7156 \\
\hline \multicolumn{6}{|c|}{$\mathrm{PM}_{2.5}$} \\
\hline Kazan & Mortality from CVD & J00-99 & All & 1.02 & 1727 \\
\hline Kazan & Mortality from RD & J00-99 & All & 1.022 & 18 \\
\hline Kazan & All-cause mortality & $\mathrm{A}_{00}-\mathrm{R}_{99}$ & All & 1.06 & 332 \\
\hline
\end{tabular}

In Vakhitovsky and Sovetsky districts, this index for the whole population made 86 and 281 per year, respectively. The absence of data on the age-specific death rate in the districts did not allow for calculating the given indices for certain age groups. Damage associated with total morbidity of asthma among the cumulative city population caused by the exposure to PM10 made 486 cases in adults and 67 cases in children per year. The possible additional number of health encounters for chronic bronchitis associated with exposure to $\mathrm{PM}_{10}$ among the child population in the city of Kazan made 122 cases per year, and among adults, it made 9919 cases per year. The possible damage on exposure to $\mathrm{PM}_{2.5}$ made an additional 15 cases of chronic bronchitis per year in Vakhitovsky district and 9 cases in Sovetsky district, 565 additional deaths from all causes (4.8\%) in the city of Kazan, 574 from cardiovascular diseases $(7.9 \%)$, and 53 from respiratory diseases $(17.7 \%)$. Damage from exposure to $\mathrm{PM}_{2.5}$ made an additional 332 deaths from all causes (14.6\%), 1727 from cardiovascular diseases $(4.5 \%)$, and 18 from respiratory diseases $(6.0 \%)$.

The major limitation of our study was the absence of the age-specific data on mortality in the city districts. However, it allowed for assessing the possible damage associated with total morbidity of chronic bronchitis and asthma in the class of "Respiratory diseases" (J00-J99), which is of great importance for the child population aged from 0 to 14 years old (Table 2). The analysis of epidemiological data in the city of Kazan and the city districts for the last ten years indicates that RD rank first in the structure of child morbidity (more than 50\%) and are environmental diseases [14]. The HRAPIE report indicates that generalization of the recommended approaches to other regions of the globe or individual countries, or to particular mixtures at the local level, may be not appropriate. Specifically, risk estimates for certain health outcomes exhibit more uncertainty [15-17]. It bears noting that the background national data on all-cause mortality have greater precision than the causespecific data. The air pollution from exposure to $\mathrm{PM}_{2.5}$ caused $14.6 \%$ of total mortality or more than 1727 cases per year, and from exposure to PM10, it caused $4.8 \%$ or 565 cases per year, respectively, for the population of the city of Kazan. The present study provides strong evidence that respiratory disease mortality ( $17.7 \%$, or 53 additional cases) and cardiovascular diseases $(7.9 \%$, or 574 additional cases) are significantly associated with $\mathrm{PM}_{10}$ in the city of Kazan. 


\section{Conclusions}

Our results enhance the existing evidence of the fact that atmospheric air pollution is a significant environmental risk factor for mortality and respiratory diseases [18-21]. A monitoring system available in large cities, insufficient account of atmospheric air pollutants prevent the correct assessment of the potential risk and actual damage for the population health. Because of limited sample volume and the aim of our study, further studies in the city of Kazan, within which the account of exposure to $\mathrm{NO}_{2}$ and black carbon, the health impacts of this exposure, and untimely mortality (which are formed in road traffic) can be used as the major indicators for PM, are required. Currently, the assessment of morbidity and diseases caused by air pollution is the starting point for development or correction of regulatory actions in the field of the environmental and the population health protection at the regional level. The quantitative assessment of the air pollution impact on the population health became the aim of the choice of policy option or options carried out for comparison of benefits from measures to decrease the ecological burden of pollution and the costs of their implementation.

Acknowledgments: This work was funded by the subsidy allocated to Kazan Federal University for the state assignment in the sphere of scientific activities 19.9777.2017/8.9.

Conflicts of Interest: The authors declare no conflict of interest.

\section{References}

1. European Environment Agency Air Quality in Europe-2015 report, EEA Report No 5/2015.

2. Fischer, P.H.; Marra, M.; Ameling, C.B.; Hoek, G.; Beelen, R.; de Hoogh, K.; Breugelmans, O.; Kruize, H.; Janssen, N.A.; Houthuijs, D. Air Pollution and Mortality in Seven Million Adults: The Dutch Environmental Longitudinal Study (DUELS). Environ. Health Perspect. 2015, 123, 697-704.

3. Zhang, P.; Dong, G.; Sun, B.; Zhang, L.; Chen, X.; Ma, N.; Yu, F.; Guo, H.; Huang, H.; Lee, Y.L.; et al. LongTerm Exposure to Ambient Air Pollution and Mortality Due to Cardiovascular Disease and Cerebrovascular Disease in Shenyang (China). PLoS ONE 2011, 6, e20827.

4. Boldo, E.; Linares, C.; Aragonés, N.; Lumbreras, J.; Borge, R.; de la Paz D.; Pérez-Gómez, B.; FernándezNavarro, P.; García-Pérez, J.; Pollán, M.; et al. Air quality modeling and mortality impact of fine particles reduction policies in Spain. Environ. Res. 2014, 128, 15-26.

5. Cárdaba Arranz, M.; Muñoz Moreno, M.F.; Armentia Medina, A.; Alonso Capitán, M.; Carreras Vaquer, F.; Almaraz Gómez, A. Health impact assessment of air pollution in Valladolid Spain. BMJ Open 2014, 4, e005999.

6. Hoek, G.; Krishnan, R.M.; Beelen, R.; Peters, A.; Ostro, B.; Brunekreef, B.; Kaufman, J.D. Long-term air pollution exposure and cardio- respiratory mortality: A review. Environ. Health 2013, 12, 43.

7. Guerreiro, C.B.; Foltescu, V.; Leeuw, F. Air quality status and trends in Europe. Atmos. Environ. 2014, 98, 376-384.

8. Beelen, R.; Hoek, G.; van den Brandt, P.A.; Goldbohm, R.A.; Fischer, P.; Schouten, L.J.; Jerrett, M.; Hughes, E.; Armstrong, B.; Brunekreef, B. Long-term effects of traffic-related air pollution on mortality in a Dutch cohort (NLCS-AIR study). Environ. Health Perspect. 2008, 116, 196-202.

9. Review of evidence on health aspects of air pollution-REVIHAAP project. Technical report. World Health Organization 2013. Available online: http://www.euro.who.int/en/health-topics/environment-andhealth/air-quality/activities/health-aspects-of-air-pollution-and-review-of-eu-policies-the-revihaap-andhrapie-projects (accessed on 12 April 2018).

10. Recommendations for Concentration-Response Functions for Cost-Benefit Analysis of Particulate Matter, Ozone and Nitrogen Dioxide 2013 Health Risks of Air Pollution in Europe-HRAPIE Project. Available online: http://www.euro.who.int/_data/assets/pdf_file/0006/238956/Health_risks_air_pollution_HRAPIE_project .pdf?ua=1 (accessed on 12 April 2018).

11. Aphekom-Improving Knowledge and Communication for Decision Making on Air Pollution and Health in Europe 2011. Guidelines of Methods for Integrating Chronic Effects of Local-Traffic Pollution in the Air Pollution Health Impact Methodology (WP4); Swiss Tropical and Public Health Institute, Basel, Switzerland; p 40. 
12. Guidelines for Health Risk Assessment for the Population on Exposure to Chemical Substances Polluting the Environment; Federal Center of the State Committee for Sanitary and Epidemiological Control: Moscow, Russia, 2004; p. 143.

13. Avaliani, S.L.; Novikov, S.M.; Shashina, T.A.; Kislitsin, V.A.; Skvortsova, N.S. Experience of use of methodology of an assessment of risk to population health for ensuring sanitary and epidemiologic wellbeing: In Works of the All-Russian Scientific and Practical Conference with the International Participation; RIO ATA: Angarsk, Russia, 2012; pp. 12-16.

14. Stepanova, N.V.; Valeeva, E.R. Main trends in children's population health in the republic of tatarstan. Gig Sanit 2015, 1, 92-97.

15. Rakhmanin, Y.A.; Novikov, S.M.; Avaliani, S.L.; Sinitsyna, O.O; Shashina, T.A. Actual problems of environmental factors risk assessment on human health and ways to improve it. Health Risk Anal. 2015, 2, 4-11.

16. Stepanova, N.V.; Fomina, S.F.; Valeeva, E.R.; Elagina, D.S.; Semanov, D.A. Non-cancer risk assessment of the atmospheric air pollution effect on the population health on the basis of evolutionary models. International Journal of Green Pharmacy. 2017, 11, 863-867.

17. Fu, J.; Jiang, D.; Lin, G.; Liu, K.; Wang, Q. An ecological analysis of PM2.5 concentrations and lung cancer mortality rates in China. BMJ Open 2015, 5, e009452.

18. Burnett, R.T.; Pope, C.A., III; Ezzati, M.; Olives, C.; Lim, S.S.; Mehta, S.; Shin, H.H.; Singh, G.; Hubbell, B.; Brauer, M.; et al. An integrated risk function for estimating the global burden of disease attributable to ambient fine particulate matter exposure. Environ. Health Perspect. 2014, 122, 397-403.

19. Kelly, F.J.; Fussell, J.C. Air pollution and public health: emerging hazards and improved understanding of risk. Environ. Geochem. Health 2015, 37, 631-649.

20. Crouse, D.L.; Philip, S.; van Donkelaar, A.; Martin, R.V.; Jessiman, B.; Peters, P.A.; Weichenthal, S.; Brook, J.R.; Hubbell, B.; Burnett, R.T. A new method to jointly estimate the mortality risk of long-term exposure to fine particulate matter and its components. Sci. Rep. 2016, 6, 18916.

21. Jerrett, M.; Burnett, R.T.; Beckerman, B.S.; Turner, M.C.; Krewski, D.; Thurston, G.; Martin, R.V.; van Donkelaar, A.; Hughes, E.; Shi, Y.; et al. Spatial analysis of air pollution and mortality in California. Am. J. Respir. Crit. Care Med. 2013, 188, 593-599. 